\title{
The Family as a Place of Education. Between a School- Centred Focus on Education and Family Needs
}

ULRIKE LOCH ${ }^{1}$

$\approx$ The results of PISA studies over recent years have revealed the social selectivity of the scholastic education system. Based on my empirical research on families with mentally ill parents, I show how, for the children involved, social exclusion begins before they even start school. I also show how parents' mental illness is seen to affect children, and what support such families require. The findings demonstrate how important it is to take family coping situations into account in education discourse concerning child and youth welfare services and formal education systems.

Keywords: child and youth welfare, child protection, social exclusion, mentally ill parents, ethnography 


\section{Družina kot mesto edukacije. Med izobraževanjem osredinjenim na šolo ter družinskimi potrebami}

ULRIKE LOCH

$\propto$ Izsledki študije PISA so v zadnjih nekaj letih pokazali na socialno selektivnost sholastičnega edukacijskega sistema. Na podlagi empirične raziskave o družinah s starši z duševnimi težavami pokažemo, kako se za vpletene otroke socialna izključenost začne, še preden začno šolanje. Pokažemo tudi, kako duševna bolezen staršev vpliva na otroke in kakšno podporo potrebujejo take družine. Izsledki kažejo, kako pomembno je, da v edukacijskem diskurzu upoštevamo tudi situacije, s katerimi se spoprijemajo družine in socialne službe, ki jih spremljajo.

Ključne besede: dobrobit otrok in mladostnikov, varstvo otrok, socialna izključenost, duševno bolni starši, etnografija 


\section{Introduction}

The basis for the following exposition is my empirical study "Kinderschutz mit psychisch kranken Eltern" (Child Protection with Mentally Ill Parents, Loch, 2014a). As part of this study, I accompanied children's social care service staff in Germany and Austria as an ethnographer while they processed child protection cases. My research focused on families in which the parents were mentally ill.

The following relates to the current discourse on families as a place for education and the effects this has on families receiving support from child and youth welfare services. Based on the example of families with mentally ill parents, I examine how the current trend towards education in child and youth welfare is affecting families coping with difficult situations. Specifically, I study the question of how a school-focused understanding of education affects child and youth welfare in practice, as well as on the support processes arranged in this context with families. This question is investigated based on a case example, preceded by a fundamental examination of the current discourse on education and the social living environment of families with mentally ill parents.

\section{The family as a place of education in social discourse}

In Germany and Austria, one significant factor for the current discourse is acknowledging that the two countries' education systems reproduce social inequalities. The results of PISA studies in recent years have revealed the social selectivity of the scholastic education system. For Austria, analyses of PISA data from 2009 show, among other things, that: "While, for example, 75\% of 15 - to 16-year-olds whose parents achieve upper secondary qualifications as their highest educational level also attend a school at that level, that number falls to $23 \%$ when parents only attend the minimal amount of compulsory education" (see Bacher, Leitgöb \& Weber, 2012, p. 432). In Austria and Germany, these repeated PISA results have led to discussion among academics and social policymakers, as well as within educational institutions, about the future development of the school education system and the importance of informal education. In the context of informal education, renewed attention is being paid to families as places of education.

\section{The family as a place of education alongside the school}

My analysis of the discourse on the family as a place of education shows that families are mainly studied as places of education alongside the school. 
Wissenschaftlicher Beirat für Familienfragen, an advisory board set up by the German government, puts it thus: "The PISA study shows [...] that the basic skills and readiness for scholastic learning and lifelong learning processes are taught to the next generation within the family. This is the basis on which human abilities are developed, in addition to the school. It affects people's choice of school type and success at school” (see BMFSFJ, 2002, p. 29). Thomas Rauschenbach et al. argue along the same lines: "The family is the first place where children are educated, and also the most important place in the period from early childhood until well into their schooldays [...]; within the family, children acquire the primary habitus which has a considerable effect on their behaviour, their attitudes, their patterns of thinking and the way they act (see Bourdieu, 1984). This means that socialisation within the family sets the course for how and how well children and young people can adapt to other forms of socialisation, especially the school. [...] Child and youth education processes are thus [...] shaped and affected by the family" (see Rauschenbach et al., 2004, p. 31).

As these illustrative quotes show, the family and success at school, or family- and school-based education, are inextricably linked in the current discourse on the family. This discourse also highlights how important educational achievements within the family are for the school as an institution, and for the scholastic success of children and young people. At the same time, the reverse question of how the school can help family educational processes is beyond discussion: discourse on the family as a place of education is currently led, above all, by the question of how the family should support the school. In the end, this school-focused thematisation of the educational expectations addressed at families allows social policy to retain its fundamental focus on the school, despite the criticism of the formal education system coming from PISA results.

\section{The school as a place where family education is recognised}

As places of education, schools in both Germany and Austria follow conventional ideals such as rationalisation, a focus on cognitive skills, hard work and good communication (e.g., see Frevert, 1999; Sting, 2010, 2013, 2014). The implicit focus among the educated bourgeoisie on family education in school sets high expectations for families and non-school organisations such as crèches, kindergartens and after-school care. The school supports processes of social inequality, as it pays little attention to how well a family's educational options and understanding of education match the prerequisites of the formal education system. If families are unable to help children meet scholastic requirements without professional support, then the expectations that the school 
holds regarding families are partly shifted towards family support schemes such as crèches, kindergartens, after-school care or home-based family support (e.g., Loch, 2011).

One thing that stands out in the discourse on the family as a place of education is that the topic of families is addressed without sufficiently taking into account the social conditions in which informal educational processes take place. For example, family educational processes are currently almost entirely addressed in the context of the discourse on formal education (see Büchner \& Brake, 2006). This points to the link between families' social recognition and their recognition by the scholastic assessment system. Based on his empirical study of the family as a place of education, Peter Büchner explains that "the question of whether a person is recognised as being educated or not depends on who recognises whom in what situation and in what accompanying circumstances, or who is expected to recognise that person in what living circumstances. Seen thus, education initially appears a relative value linked to different understandings of education, depending on where someone positions themselves on the map of different educational profiles or where they are positioned by others" (see Büchner, 2006b, p. 11). School is currently the central education system that, thanks to processes of inclusion and exclusion, indirectly recognises or refuses to recognise processes of family education (see Büchner \& Wahl, 2005).

\section{The school, the family and pedagogical schemes outside the school}

Notwithstanding the explicit reference to Pierre Bourdieu (1984), if social power relations are ignored, this encourages a shift of responsibility for the success or failure of scholastic education from the school to the schoolchildren's families of origin. This tendency can be seen in the discourse on the family as a place of education. "Many aspects which are attributed to the school [...] in fact cannot be ascribed entirely or even mainly to the school; [...] a sizeable number of problems identified in school [...] are the result of everyday education rather than the school as a formal place of education; learning which it is evidently being acquired as a matter of course by a dwindling number of adolescents" (see Rauschenbach, 2007, p. 446). The solution to this problem is seen as extending the number of full-service community schools and daycare providers. These pedagogical schemes are expected to increasingly replace families as places for informal education (see Rauschenbach, 2007). This line of argument - that the social relationship between families and pedagogical schemes needs to be reconfigured - shows little trust in families and their processes of education, especially when those families are defined as being disconnected from formal education 
(bildungsfern). Mistrust towards families is particularly evident "if they are poor and socially and educationally deprived" (see Helming, 2013, p. 49). It is not unusual for the school's mistrust of marginalised families to come hand in hand with calls for increased state control (see Helming, 2013; Loch, 2011). This discussion on places of education to complement the family overlooks the fact that "the family's educational and cultural achievements (in both positive and negative circumstances) must be seen as key variables in the acquisition of education, in children's educational career and in their educational success" (see Büchner, 2006a, p. 40). Families are always significant in this way, however greatly a family's educational achievements may differ from a school's expectations.

\section{Research design}

The central research questions in the present study are: How do youth welfare services process child protection cases with mentally ill parents? What are the professional, social and organisational conditions behind the youth welfare department's child protection casework, and how do they affect the support process? This wide spectrum of questions meant that the research not only involved cooperation with child and youth welfare services and the education and health system, but also touched on the families' living conditions.

As part of my study, I carried out ethnographical observations of youth welfare workers dealing with child protection cases at a total of four youth welfare departments: two in Germany and two in Austria. The ethnographic surveys took place between 2008 and 2012. In empirical terms, ethnography is about "bringing attention to a field of practised sociality" (see Amann \& Hirschauer, 1997, p. 11). In the fields of social work and education, observations have revolved around social pedagogical practice (see, for example, the studies by Cloos, 2008; Riemann, 2000; Wolff, 1981). In the case of child protection, "ethnographical observation" meant that, among other things, I was present during telephone conversations, while advice was given to parents, and during cooperation with various institutions, as well as at team meetings, home visits and care proceedings. In other words, I studied the full range of professional practice in the field of child protection. My results are thus based on a research method that is closely linked to practice in child and youth welfare.

Every day, I took ethnographical notes on my research trips, while some support processes were also recorded electronically. In certain cases, the ethnographical observations were supplemented by interviews with professionals and data collected from youth welfare files or artefacts such as child protection statistics created at youth welfare departments. The results are thus based on a 
broad database covering both the professionals' actions and the organisation.

The main focus of my study was child protection cases with mentally ill parents. The feature shared by the cases chosen for the reconstruction is that at the time the risk was reported, the children were younger than age six, and their parents were mentally unstable or ill. These were the central selection criteria for the theoretical sampling (see Strauss \& Corbin, 1990). The broad range of the research method and the decision, developed within Grounded Theory, not to distinguish between the stages of data collection and evaluation (see Strauss \& Corbin, 1990) meant that it was possible to reconstruct not only situational professional practice at the youth welfare department but also the genesis of the observed child protection cases. In other words, it enabled a reconstruction of the full range of child protection procedures.

The data collected were interpreted using hermeneutic perspectives (see Gall, Borg \& Gall 1996; Oevermann, 1993; Rosenthal, 2004). The analysis results for the different data types (interviews, ethnographical notes, etc.) were then triangulated to reconstruct the processes by which child protection cases are established, and how the cases progress. This point of view means that the research results do not so much reflect "natural" child protection problems as the way cases are formed interactively (see Loch \& Schulze, 2005) based on organisational, professional, personal, familial, legal, political and socio-political factors. The results of this study thus link in with the results of Stephan Wolff's ethnomethodological study of youth welfare departments, according to which the practical value that municipal social work offers its official clients is not systematic, following a practical logic, but is, ultimately, political (see Wolff, 1981, p. 3). In other words, the study results point to the social constitutionality of the problems in the social and education system produced, inter alia, by the social disadvantages of children and families with mentally ill parents.

\section{On the living situations of families with mentally ill par- ents: empirically grounded results}

Below, I focus on the living situations of families with mentally ill parents receiving support from child and youth welfare services with the aim of promoting the child's best interests. As the article continues, I will establish a link between the living situation of the children involved and their educational careers in the context of the discourse on education.

My research results reveal that the living situations of families with mentally ill parents share similar traits in terms of family background, family relationships, social exclusion, daily routine and the support procedure. These 
shared traits are so consistent that they indicate the social constitution of the coping strategies found in the families.

To link in with the works of Lothar Böhnisch (2005), "coping" (Bewältigung) means that the people involved are in difficult living situations in which their own actions have little influence, and in which they nonetheless - according to their own possibilities - attempt to find their bearings, trying to find positive self-esteem and support in close relationships. "Coping strategies are based [...] on 'learning survival skills', arising from a biographical confrontation with psychosocial burdens" (see Sting, 2014, p. 181) in their specific social context. Below, I look into the form those burdens take for families with mentally ill parents and the work that this can imply for social pedagogues in contexts of coping.

\section{Mental illness as a coping attempt that may be socially accepted}

The parents' mental illnesses relate to trauma suffered in their childhood and/or youth. This trauma and its effect have such a major presence in the families, especially on the level of interaction, that the children suffer from the consequences of the trauma and their parents' mental illness through their transgenerational relationship. The parents' mental illnesses are reactions to traumatic childhood experiences in socially difficult living environments; at the same time, they are accepted within the family as an attempt to cope. In addition to the parents' mental illness (and often that of other family members), the affected families show signs of other problems such as an increased tendency to suicide and alcohol consumption, domestic violence and/or unemployment. As such, the families suffer from a combination of problems that indicate a multigenerational need for support (see Loch, 2014a, b).

\section{The children's wellbeing may be an unattainable aim for parents}

All of the mentally ill parents involved in the study are interested in their children's wellbeing. This motivation has led many of the parents affected to seek help within the family and/or low-threshold support from pedagogical institutions or psychosocial professionals. To a large extent, parents have managed to protect their children against directly exercised violence, such as psychological and sexual violence, which they themselves suffered in their childhood and/ or youth. Nonetheless, they have unintentionally drawn their children into the problems of their family of origin across the generations via the parent/child relationship. This has led the children into parentification, resulting in experiences of neglect and psychological violence, without the parents noticing these 
processes of parent/child role reversal. The results of these parent/child interactions, centred around the parents' needs, were seen in children as developmental delays in areas relevant to special needs (such as motor skills, speech, play and social behaviour) and in cognitive/emotional areas. These developmental delays, which are observed from early childhood on and can become a disadvantage in terms of access to formal education, are not coincidental, as current research into attachment theory shows. A reliable attachment is considered "an early emotional and cognitive prerequisite for education" (see Ziegenhain \& Gloger-Tippelt, 2013, p. 793). Reliable social interaction and relationships form the basis on which children can develop the ability to communicate their thoughts and feelings, as well as developing structurisation skills. Childhood structurisation skills are understood as the ability to solve problems in line with the child's age and developmental stage. The affected children's developmental deficits first become salient when the children are integrated into pedagogical schemes such as daycare groups and centres. The pedagogical staff at the daycare facility are usually the first to point out to parents that their children have developmental delays, and these are usually at an advanced stage from a professional point of view. In all of the families, the pedagogical staff have to spend a great deal of time providing parents with information before they recognise the children's need for support and (where possible) can help the children cope with the tasks assigned to them. In other words, mentally ill parents are a group that, due to their own childhoods, have a great need for professional support in looking after, encouraging and/or caring for their children, as well as a need for intensive supported parenting lessons, so as to take on the child-friendly parenting role they would like. This need for supported parenting applies to all parents who are interested in their children's wellbeing, even if the children are in out-of-home care.

\section{Parent-centric parent-child interactions starting in early childhood}

Viewed retrospectively, the first problems with parent-child interactions occur when the child is a babe in arms. During consultations, the parents sometimes made comments such as "The problems started when our child was two months old". Such parental observations correspond with clinical experience; at just nine months old, parentified parent-child interactions are observed in babies, a phenomenon that can be interpreted as children adapting to their parents' style of interaction (see Deneke, 2005). These coping strategies initially make the children's and families' lives easier. However, if children in these overly demanding situations do not receive any support, these parentifying coping 
strategies become ingrained. In the long term, parentification is a means of coping that is of more harm than good for children's development. As a result, the children show signs of behavioural problems and delayed development, which can go as far as the parent-child relationship being seen as endangering the child's wellbeing.

The parents' difficulties in interacting with their children grow as the children show signs of wanting autonomy in line with their developmental stage. These processes of autonomy mostly open up for the children through their integration into daycare provisions such as centres, groups or childminding. Autonomy processes represented such a great threat to all of the parents that, when possible, they took their children out of childcare, etc. for fear of losing them.

All of the mentally ill parents in the study have a great need for support in understanding the child development process and in dealing with their own fear of loss. On the part of the parents, this need for support usually starts out with basic, but existentially threatening questions such as "Why doesn't my child want to cuddle me when I come to the daycare centre?" or "Why does my child want to play with another child now instead of letting me read him a book?" Mentally ill parents often interpret new behaviour in their children, such as adapting to a peer group (e.g., at the daycare centre), as rejection. In all child protection cases, processes of autonomy in the children cause such a strong fear of loss in the parents that they start to act as if staff (e.g., at the daycare centre) are in competition with them. They threaten to take their children out of daycare and sometimes do even take them out. In some cases, even primary schoolers stayed away from the school so as to protect their parents.

In fear-ridden situations of this kind, those parents who were in touch with their families of origin were supported by the latter in taking their children out of care and support (such as the daycare centre or childminding) in favour of a greater focus on the family. In other words, staff need to work hard with the parents, supporting them in their emotional needs and translating the children's needs into a language that the parents understand. This is the only way to stop the parents and children from acting as if there is a competition (with professionals) for emotional attention and thus retreating from society and cancelling daycare arrangements. Tendencies to retreat into the family as a central point of reference in socially difficult situations can be observed in parents and children alike, whatever the actual resources offered by the family of origin. One key trigger for self-exclusion is when pedagogical staff question parentcentric parent-child interactions without offering the parents alternative forms of support. For the parents, parent-centric parent-child relationships are, after all, transgenerational attempts at coping, without which life seems even harder. 
Parentifying parents cannot usually appreciate the effect that parent-centric behaviour has on their children. This does not, however, make the effect on their children any less destructive.

In the literature, this pattern of behaviour, where parents largely give up their function as parents to their children, is described as "emotionally destructive parentification". Johannes Graf and Reiner Frank describe emotionally destructive parentification thus: "Parentifying parents abandon their function as parents. They (mis-)use their child to satisfy their unmet needs, neglecting or ignoring the child's own needs. This gives the child an inappropriate role that crosses generational borders. [...] The child accepts this delegated role at the cost of its own needs, learning and displaying patterns of behaviour to suit that (inappropriately responsible, caring) role" (see Graf \& Frank, 2001, pp. 317-18; Boszormenyi-Nagy \& Spark, 1973; Jurkovic 1997; Loch 2014a, b). Emotionally destructive parentifying parents find emotional stability through the parentchild relationship to such an extent that even when the parent and child are separated only temporarily this can lead the parent to be destabilised even further. Among highly traumatised parents, the fear of such destabilisation can be triggered by their children being integrated into daycare centres or full-service community schools. If this parental destabilisation is not picked up by traumasensitive work with parents accompanying the pedagogical provisions, it can worsen symptoms of an illness, especially among single parents. Children who have undergone emotionally destructive parentification may react to their parents' mental processes with greater social aberrance and developmental deficits. This can manifest itself, for example, as children behaving uncharacteristically in daycare, having previously been considered to be well-integrated there. Pedagogical staff rarely interpret this aberrant behaviour as an interactive pattern learnt through the parent-child relationship; their interpretations mainly concentrate on the child, with the child being described as difficult.

\section{Socially isolated families with reduced access to social education}

One point that stands out is families' social isolation, which often accompanies poverty and limited access to recreational and educational schemes. As a result, the children's social contacts in their early years are largely limited to their families, meaning that during this period they mainly learn relational and interactional patterns that fall within the context of psychological aberrance and coping. One example of this is fear-ridden parent-child interactions in which children are rarely challenged to test their own limits or explore their environment. Among other things, this can result in ritualised patterns of play 
and the avoidance of new situations, such as learning new games at the daycare centre. These restrictions can be interpreted as reduced access, starting in very early childhood, to socially accepted forms of education: "Different types of family of origin produce and pass on specific cultural practices which extend to all aspects of how people lead their lives. These have different levels of affinity to socially legitimated and rewarded practices" (see Sting, 2013, p. 49). Thus, even in very early childhood, the children in question show signs of social practices which are not very compatible with the school-focused educational expectations demanded of families, and which have little chance of earning social recognition in the formal education system and beyond.

In the first contexts they encounter outside their family, such as children's groups or daycare centres, the patterns of interaction that the children have learnt in their family mean that they experience social exclusion, to which they tend to react with self-exclusion. The patterns of interaction in their family are largely incompatible with the dominant social expectations. For example, in daycare centres, one aspect that stands out is that the children in question rarely play with peers (or are unable to do so) thanks to their isolated upbringing by their parents, and thus tend to seek contact with adults. Thus, even in very early childhood, children who have grown up in isolated families with relational patterns encumbered by illness and trauma display patterns of interaction that: a) exclude them socially, resulting in them excluding themselves; b) limit their access to social (and thus to formal) education; and c) risk their continuing their parents' isolated, illness-encumbered life or reproducing its patterns.

Parent-child interactions are tainted by the parents' unprocessed traumatic experiences, which they pass on to the children in the form of high expectations of loyalty. Family secrets, taboos and experiences that cannot be put into words have a long-term effect on family interactions (see Imber-Black, 1993; Rosenthal, 1998); their latent nature can lastingly prevent the development of autonomy and participation (see Loch, 2006, 2014b). Family interactions instil rules (e.g., social rules) and loyalties that give members of the family different degrees of freedom to become independent or to access education, or that limit processes of autonomy, expressed, inter alia, as dropping out of education (see Loch 2014b). In families with mentally ill parents, the shift in generational borders means children are expected to show loyalties and take on delegated tasks that clash with the tasks they face at their particular developmental stage, and with educational requirements within society (at the daycare centre or school). Without support, when such clashes occur, children (or families) tend to repeat behaviour that stabilises the family, resulting, inter alia, in their leaving child and youth welfare schemes or daycare centres, or dropping out of school. 


\section{Child-friendly daily routines}

In all families, creating a child-friendly daily routine is a difficult task which parents cannot always achieve. As a result, some children are forced to become independent at an early age, as is evident, for example, in a child having to collect yoghurt under his bed as a reserve of food for days on which he was not given anything to eat. Others have a highly controlled daily routine with no exceptions allowed, leaving children no room for manoeuvre and limiting their opportunities to become independent. In the case of food, this results in the same meals always being served (punctually), with the child having to eat the same amount every day, regardless of how hungry s/he is. Any change in this practice (whether it is a lack of routine or excessive routine) is a major cause of stress and mental effort for mentally ill parents, meaning that such changes cannot be achieved through walk-in support, with no other support. Instead, if the parents live with their children, what is needed is longer-term social pedagogical guidance within the families' everyday lives and therapy to enable the parents to untangle the daily family routine from their own emotional needs.

In terms of relationships, these problems in establishing a routine emerge for all parents as difficulties setting limits for their children, either as a lack of limits or as highly controlled, fixed limits. Such problems in establishing a routine make it hard for parents to gain authority over children, or lead children to take on responsibility for their parents' wellbeing. In other words, the daily routine reflects the results of emotionally destructive parentification.

\section{Child protection support procedure}

All of the child protection cases reconstructed for my study proceeded the same way. The families started out with walk-in support from child and youth welfare services, then went on to receive out-of-home support. For the children, this procedure often involved repeated changes of childcare facilities such as daycare centres and/or foster families. This series of steps is currently symptomatic of child protection work with mentally ill parents in Germany and Austria. The similar way in which support is provided can be explained by the fact that child and youth welfare services and the education system have insufficient resources, meaning out-of-home care is their only possible answer to medium-term threats to the child's wellbeing arising from emotionally destructive parentification. The result of this lack of resources by child and youth welfare services for families with mentally ill parents is evident in the high number of cared-for children with mentally ill parents (see Leitner, Loch \& Sting, 2011). 
At the same time, it can be seen that the destructive mess caused by parentifying child-parent relationships cannot be unravelled through child-focused pedagogical or therapeutic schemes alone (Loch, 2011, 2014b; Schmid, 2007).

Another parallel is the question of whether such children can complete their educational path at a mainstream school, a question that regularly arises in collaboration between the youth welfare services and the daycare centre or school. For many children subject to emotionally destructive parentification, even those in out-of-home care, this question arises while they are still at kindergarten: the school asks whether their level of development meets scholastic requirements. Among older children, situations frequently occur in which the school calls for the children to enter out-of-home care (see Loch, 2011). This reflects the school's expectation that children should acquire informal education within their milieu of origin, forming the basis for the concept of children being "ready for school" as held by the school as a system of formal education. When families do not fulfil these expectations, extrafamilial, professional foster families or residential childcare are expected to take over. These requirements reflect existing controls on marginalised families, as expected by society.

\section{Case example}

I would now like to illustrate what has been described above with the case of Florian Titzan. As a baby, Florian grew up with a single mother who drew mental stability from the mother-child relationship. In the years before his birth, his mother gained support from schooling and vocational training, but when she fell pregnant, memories of violent childhood experiences increasingly occupied her thoughts. After Florian's birth, Ms Titzan was initially supported by her family, before asking to be taken into psychiatric care along with the baby. When the mother was released from adult psychiatric care, a child welfare risk report was sent to the relevant youth welfare department, and the mother sought help from the same source. As a result, on being released from hospital, the mother received various forms of walk-in support from child and youth welfare services, before asking for her child to be cared for in a foster family, as she was unable to cope with everyday life. The mother's intention was to make sure that her child was being taken care of, while at the same time combining parenthood, vocational training and her mental stability more effectively.

After Florian was taken into a foster family, he developed in leaps and bounds. Ms Titzan's reaction to Florian's development was positive, but at the same time the autonomy of her child's progress triggered fears of loss in the mother. During the period that followed, Florian cried a lot, especially when 
in contact with his mother. As the analysis shows, the three-year-old's developmental progress brought him into a conflict of loyalties between his wellbeing in the foster family and his responsibility towards his mother. Ms Titzan made an impulsive decision to take Florian out of foster care, explaining that it was because of his regular crying and her own conflicts with the foster family. This pattern of conflict was repeated with the subsequent foster family, meaning that Florian finally entered his third foster family at the age of four. Despite intermediary phases of stability and the development of skills, by the age of five the little boy thus had such extensive deficits in his motor skills, social competence and language development that he was unable to attend a mainstream school.

Florian was initially given another year before starting school, intended to enable him to attend mainstream schooling, and received support within the third foster family from a daycare centre and an early-learning programme. The early-learning programme was designed to help him learn the motor skills and language required by the school. At the same time, the early-learning centre worked with Florian's birth mother, who wanted her child to be returned to her by the time he started school. This dual role taken on by the early-learning centre unintentionally meant that its work revolved around the mother's wishes for their relationship. As a result, parentifying elements of the mother-child relationship were reinforced in the context of early learning. This was possible because the professionals reflecting on the case paid too little attention to the effects that the parent-child relationship was having on the little boy.

Only the foster family was called upon to promote the child's social skills: "Early-year support [...] aimed at preparing Florian for school; the social deficits are not being processed, much to the regret of Ms Merhard [the foster mother, U.L.]" (excerpt from the youth welfare department file). As Florian grew older, his social behaviour increasingly showed parallels with that of his mother, who had largely retreated into social isolation. For example, Ms Titzan had to give up her vocational training due to basic communication problems in the workplace. Florian showed signs of similar communication difficulties: "Florian quickly grows frustrated and cries because other children are unable to deal with his form of communication. The children and Florian then do not understand one another" (excerpt from the youth welfare department file). When the youth welfare department realised that Florian would not be able to attend a mainstream school due to his developmental delays, a special needs school was sought out and the child was appraised by the department of child psychiatry.

Cases are frequently seen to develop in this way in the field of child and youth welfare services. This means that when the support services offered by child and youth welfare services focus on the educational requirements demanded of 
families by the school, without at the same time improving the family's educational resources, formal education can remain on a risky course for children subjected to destructive parentification. When they do not manage to enter a mainstream school, the children are additionally confronted with childhood psychiatry diagnoses. The children run the risk of becoming isolated and reproducing their parents' difficult life courses. If children receive adequate support and institutions simultaneously offer to work with parents in a child-focused manner, the parents and children can have experiences of autonomy that help them cope with difficult situations in life and with educational processes.

\section{Emphasis on formal education increasingly extending to kindergarten children}

As discussed in detail at the start of this work, the current focus on the family as a place of learning involves school-centric informal educational processes that are in line with the ideals of the educated bourgeoisie. At the same time, the call for school-focused pedagogical provisions, such as afterschool daycare or full-service community schools, mainly addresses contexts outside the family that are intended to help families fulfil their educational role. For marginalised families, these pedagogical provisions are intended to tackle school-focused educational work in place of the family. Little educational trust is placed in these families. Meanwhile, the empirically unproven idea that pedagogically initiated educational processes can tackle school-based informal education instead of these families with an educational disconnect means that pedagogical professionals face high expectations. Whether these can be fulfilled is doubtful, as the results of studies to date tend to indicate the importance of cooperation between the parents and the school (and any other support) as a means of avoiding educational disadvantages (see Büchner \& Wahl, 2005). The results of my study show that separating children from their families does not (alone) encourage them to become involved in school-focused educational processes; instead, the children still feel a part of their parents. This is why, as well as supporting the children, professionals also need to work with parents, focusing on the child, encouraging processes of family education and helping families cope with their difficult situations in life. Then, and only then, will educational processes - meaning successful access to mainstream schooling and formal school qualifications - become more achievable even for children from vulnerable families with mentally ill parents.

Education policy can oblige children to take part in school-focused educational contexts outside the family, such as those at full-service community 
schools. However, it cannot prevent them from processing what they learn in pedagogical contexts on the basis of familial experiences of learning (even when physically separated from their family). Nonetheless, one thing that pedagogical professionals and school social workers can do - if they succeed in recognising the contributions that families make to education - is to help children and parents shape processes of familial education. Among other things, this requires them to think of coping as an everyday reality for children in education. This would lead to pedagogical provisions being offered by schools and youth welfare services that are more closely aligned than previously to the needs of marginalised clients. Children, young people and their parents would then less frequently be placed in the situation of having to choose between their families and school. Children and young people can be helped to find a balance between their family loyalties and formal educational requirements by offering them inclusive perspectives on how to process differences (see Sting \& Wakounig, 2008, p. 8). This presumes that daycare facilities and schools also see it as their task to promote informal education, an understanding of their task that can be derived from the UN Convention on the Rights of the Child (1989). Children have a right to their families and a right to education, and this needs to be taken into account when designing formal and informal educational schemes. Enforcing children's rights requires responsible cooperation between the formal education system, the child and youth welfare services and families, all on an equal footing. In practice, this needs to take into account all of the parties' resources and hierarchies, while simultaneously enabling them to participate. Only then can families and schools become equal places of informal education; only then can schools become democratic places of formal education.

\section{References}

Amann, K., \& Hirschhauer, S. (1997). Die Befremdung der eigenen Kultur. Ein Programm [Estrangement of One`s Own Culture. A Programme]. In S. Hirschhauer \& K. Amann (Eds.), Die Befremdung der eigenen Kultur. Zur ethnographischen Herausforderung soziologischer Empirie [Estrangement of One's Own Culture. On the Ethnographical Challenge of Sociological Research] (pp. 7-52). Frankfurt: Suhrkamp.

Bacher, J., Leitgöb, H., \& Weber, C. (2012). Bildungsungleichheiten in Österreich. Vertiefende Analyse der PISA 2009-Daten [Educational Inequalities in Austria. Further Analysis of the Austrian PISA Results of 2009]. In F. Eder (Ed.), PISA 2009. Nationale Zusatzanalysen für Österreich [PISA 2009. Austrian National Analyses] (pp. 432-456). Münster: Waxmann. Böhnisch, L. (2005). Sozialpädagogik der Lebensalter. Eine Einführung [Social Pedagogy of the Human Ages. Introduction] (4th rev. ed.). Weinheim: Juventa. 
Boszormenyi-Nagy, I., \& Spark, G. M. (1973). Invisible loyalties. Reciprocity in intergenerational family therapy. New York: Harper \& Row.

Bourdieu, P. (1984). Distinction. A social critique of the judgement of taste. Cambridge, MA: Harvard University Press (French orig. 1979).

Büchner, P. (2006a). Der Bildungsort Familie. Grundlagen und Theoriebezüge [The Family as an Educational Space. Basics and Theory]. In P. Büchner, \& A. Brake (Eds.), Bildungsort Familie. Transmission von Bildung und Kultur im Alltag von Mehrgenerationenfamilien [The Family as an Educational Space. Communicating Culture and Education in the Everyday Lives of ThreeGeneration Families] (pp. 21-48). Wiesbaden: VS.

Büchner, P. (2006b). Zur Einführung. Die Familie als Bildungsort [Introduction. The Family as an Educational Space]. In P. Büchner \& A. Brake (Eds.), Bildungsort Familie. Transmission von Bildung und Kultur im Alltag von Mehrgenerationenfamilien [The Family as an Educational Space. Communicating Culture and Education in the Everyday Lives of Three-Generation Families] (pp. 11-20). Wiesbaden: VS.

Büchner, P., \& Brake, A. (2006). Transmission von Bildung und Kultur in Mehrgenerationenfamilien im komplexen Netz gesellschaftlicher Anerkennungsbeziehungen. Resümee und Ausblick.

[Communicating Culture and Education as an Aspect of Acknowledgement in Three-Generation Families. Results and Perspectives]. In P. Büchner \& A. Brake (Eds.), Bildungsort Familie. Transmission von Bildung und Kultur im Alltag von Mehrgenerationenfamilien [The Family as an Educational Space. Communicating Culture and Education in the Everyday Lives of ThreeGeneration Families] (pp. 255-277). Wiesbaden: VS.

Büchner, P., \& Wahl, K. (2005). Die Familie als informeller Bildungsort. Über die Bedeutung familialer Bildungsleistungen im Kontext der Entstehung und Vermeidung von Bildungsarmut [The Family as a Space for Informal Education. The Relevance of Familial Education in the Context of Educational Disadvantage]. Zeitschrift für Erziehungswissenschaft, 8(3), 356-373.

Bundesministerium für Familie, Senioren, Frauen und Jugend (BMFSFJ, Wissenschaftlicher Beirat für Familienfragen). (2002). Die bildungspolitische Bedeutung der Familie - Forderungen aus der PISA-Studie [The Significance of Families in Educational Policy - Consequences of the PISA Study]. Stuttgart: Kohlhammer.

Cloos, P. (2008). Die Inszenierung von Gemeinsamkeit. Eine vergleichende Studie zu Biografie, Organisationskultur und beruflichem Habitus von Teams in der Kinder-und Jugendhilfe [Enacting Communality. Comparative Analysis of Biography, Organisational Culture and Habitus in Youth Welfare Teams]. Weinheim: Juventa.

Deneke, C. (2005). Misshandlung und Vernachlässigung durch psychisch kranke Eltern [Maltreatment and Neglect by Mentally Ill Parents]. In G. Deegener \& W. Körner (Eds.), Kindesmisshandlung und Vernachlässigung. Ein Handbuch [Maltreatment and Neglect. A Manual] (pp. 141-154). Göttingen: Hogrefe.

Deneke, C. (2009). Kinder psychisch kranker Eltern [Children with Mentally Ill Parents]. In H. Schlack, R. v. Kries, \& U. Thyen (Eds.), Sozialpädiatrie. Gesundheitswissenschaft und pädiatrischer 
Alltag [Social Paediatrics, Health Science and Paediatric Practice] (pp. 396-403). Berlin: Springer. Frevert, U. (1999). Renaissance der Bürgerlichkeit? Historische Orientierungen über die kulturellen Ressourcen der Wissensgesellschaft [Renaissance of the Bourgeoisie? Historical Approaches to the Cultural Resources of a Knowledge-Based Society]. In F. W. Graf, A. Platthaus, \& S. Schleising (Eds.), Soziales Kapital in der Bürgergesellschaft [Social Capital in Civic Society] (pp. 147-160). Stuttgart: Kohlhammer.

Gall, M. D., Borg, W. R., \& Gall, J. P. (1996). Educational research. An introduction (6th rev. ed.). New York: Longman.

Graf, J., \& Frank, R. (2001). Parentifizierung. Die Last, als Kind die eigenen Eltern zu bemuttern [Parentification. The Burden Borne by Children Mothering their Own Parents]. In S. Walper, \& R. Pekrun (Eds.), Familie und Entwicklung. Aktuelle Perspektiven der Familienpsychologie [The Family and Development: Current Perspectives from Family Psychology] (pp. 314-341). Göttingen: Hogrefe. Helming, E. (2013). Arroganz der Kontrolle oder Wege der Anerkennung [The Arrogance of Control, or Routes to Recognition]. In Die Kinderschutz-Zentren (Ed.), Aufbruch. Hilfeprozesse gemeinsam gestalten [A Brave New Start. Shaping Support Processes Together] (pp. 49-93). Cologne: Bundesarbeitsgemeinschaft der Kinderschutz-Zentren.

Imber-Black, E. (Ed.) (1993). Secrets in families and family therapy. New York: Norton.

Jurkovic, G. J. (1997). Lost childhoods. The plight of the parentified child. London: Brunner-Routledge. Leitner, S., Loch, U., \& Sting, S. (2011). Geschwister in der Fremdunterbringung. Fallrekonstruktionen von Geschwisterbeziehungen in SOS-Kinderdörfern aus der Sicht von Kindern und Jugendlichen [Siblings in Out-of-Home Care. Case Reconstructions of Sibling Relationships in SOS Kinderdorf Villages as Seen by Children and Young People]. Vienna: Lit.

Loch, U. (2006). Sexualisierte Gewalt in Kriegs- und Nachkriegskindheiten. Lebens- und familiengeschichtliche Verläufe [Sexualised Violence in Childhood During and After War. Paths Taken in People's Lives and Family Histories]. Opladen: Budrich.

Loch, U. (2011). Familiale Gewalt, schulische Inklusion und professionelles sozialpädagogisches Handeln [Family Violence, School Inclusion and Professional Social Pedagogical Practice]. In S. Sting, \& V. Wakounig (Eds.), Bildung zwischen Standardisierung, Ausgrenzung und Anerkennung von Diversität [Education Amongst Standardisation, Exclusion and the Recognition of Diversity] (pp. 179-197). Vienna: Lit.

Loch, U. (2014a). Kinderschutz mit psychisch erkrankten Eltern. Ethnografie im Jugendamt [Child Protection with Mentally Ill Parents. Ethnographic study of children's care services]. Weinheim: Beltz Juventa.

Loch, U. (2014). Prekinitev izobraževanja zaradi družinske lojalnosti? Večgeneracijska perspektiva kot profesionalni izziv v skrbi za otroke in mladostnike [Termination of education due to family loyalty. Multigenerational perspective as professional challenge in care of children and youth]. Sodobna pedagogika, 57(3), 42-53 Loch, U., \& Schulze, H. (2005). Biografische Fallrekonstruktion im handlungstheoretischen Kontext der Sozialen Arbeit [Biographical Case Reconstruction in the Context of Action Theory in Social 
Work]. In W. Thole (Ed.), Grundriss Soziale Arbeit. Ein einführendes Handbuch [Outlines of Social Work. An Introductory Handbook] (pp. 559-576). Wiesbaden: VS.

Oevermann, U. (1993). Die objektive Hermeneutik als unverzichtbare methodologische Grundlage für die Analyse von Subjektivität. Zugleich eine Kritik der Tiefenhermeneutik [Objective Hermeneutics as an Indispensable Methodological Basis for Analysing Subjectivity. Also a Critique of In-Depth Hermeneutics]. In T. Jung \& S. Müller-Doohm (Eds.), Wirklichkeit im Deutungsprozess. Verstehen und Methoden in den Kultur- und Sozialwissenschaften [Reality in the Interpretation Process. Understanding and Methods in Cultural and Social Sciences] (pp. 106-189). Frankfurt: Suhrkamp. Rauschenbach, T. (2007). Im Schatten der formalen Bildung. Alltagsbildung als Schlüsselfrage der Zukunft [In the Shadow of Formal Education. Everyday Education as a Key Future Issue]. Diskurs Kindheits- und Jugendforschung, 2(4), 439-453.

Rauschenbach, T., Mack, W., Leu, H. R., Lingenauber, S., Schilling, M., Schneider, K., \& Züchner, I. (2004). Konzeptionelle Grundlagen für einen Nationalen Bildungsbericht. Non-formale und informelle Bildung im Kindes- und Jugendalter [Conceptual Basis for a National Report on Education. NonFormal and Informal Education in Childhood and Adolescence]. Berlin: BMBF.

Riemann, G. (2000). Die Arbeit in der sozialpädagogischen Familienberatung. Interaktionsprozesse in einem Handlungsfeld der sozialen Arbeit [Work in Social Pedagogical Family Support. Interaction Processes in a Field of Social Work Practice]. Weinheim: Juventa.

Rosenthal, G. (Ed.) (1998). The Holocaust in three generations. Families of victims and perpetrators of Nazi regime. London: Cassell.

Rosenthal, G. (2004). Biographical Research. In C. Seale, G. Gobo, J. F. Gubrium, \& D. Silverman (Eds.), Qualitative research practice (pp. 48-64). London: Sage.

Sameroff, A., Seifer, R., Zax, M., \& Barocas, R. (1987). Early indicators of developmental risk: Rochester longitudinal study. Schizophrenia Bulletin, 13(3), 383-394.

Schmid, V. (2007). Nähe und Distanz aus der Perspektive der Psychoanalytischen Pädagogik [Closeness and Distance from the Perspective of Psychoanalytical Pedagogy]. In M. Dörr \& B. Müller (Eds.), Nähe und Distanz. Ein Spannungsfeld pädagogischer Professionalität [Closeness and Distance. A Balancing Act by Pedagogical Professionals] (pp. 47-58). Weinheim: Juventa.

Sting, S. (2010). Soziale Bildung [Social Education]. In W. Schröer, \& C. Schweppe (Eds.), EEO. Enzyklopädie Erziehungswissenschaft Online [Online Encyclopaedia of Educational Science]. Weinheim: Juventa.

Sting, S. (2013). Bildung im Kontext. Perspektiven von Selbstbildung im Rahmen sozialer Formierungs- und Differenzierungsprozesse [Education in Context. Perspectives on Self-Education in the Context of Social Processes of Shaping and Differentiation]. In S. Ahmed, A. Pohl, L. V. Schwanenflügel, \& B. Stauber (Eds.), Bildung und Bewältigung im Zeichen von sozialer Ungleichheit. Theoretische und empirische Beiträge zur qualitativen Bildungs- und Übergangsforschung [Education and Coping Against a Background of Social Inequality. Theoretical and Empirical Work in Qualitative Research on Education and Transitions] (pp. 34-46). Weinheim: Beltz Juventa. Sting, S. (2014). Überleben lernen [Learning to Survive]. In M. Göhlich, C. Wulf, \& J. Zirfas (Eds.), 
Pädagogische Theorien des Lernens [Pedagogical Theories of Learning] (pp. 176-187). Weinheim: Beltz Juventa.

Sting, S., \& Wakounig, V. (2008). Bildung zwischen Standardisierung, Ausgrenzung und Anerkennung von Diversität - zur Einführung [Education Amongst Standardisation, Exclusion and the Recognition of Diversity - an Introduction]. In S. Sting, \& V. Wakounig (Eds.), Bildung zwischen Standardisierung, Ausgrenzung und Anerkennung von Diversität [Education Amongst Standardisation, Exclusion and the Recognition of Diversity] (pp. 3-15). Vienna: Lit. Strauss, A. C., \& Corbin, J. (1990). Basics of qualitative research. Techniques and procedures for developing Grounded Theory. London: Sage.

United Nations (UN). (1989). Convention on the rights of the child. New York: UN. Retrieved 06.11.2016 from http://www.ohchr.org/en/professionalinterest/pages/crc.aspx.

Wolff, S. (1983). Die Produktion von Fürsorglichkeit [The Production of Compassion]. Bielefeld: AJZDruck.

Ziegenhain, U., \& Gloger-Tippelt, G. (2013). Bindung und Handlungssteuerung als frühe emotionale und kognitive Voraussetzungen von Bildung [Attachments and Agency as Early Emotional and Cognitive Prerequisites of Education]. Zeitschrift für Pädagogik, 59(6), 793-802.

\section{Biographical note}

Ulrike Loch is an Associate Professor for Social Pedagogy at the Institute of Educational Science and Research, University of Klagenfurt (AAU Klagenfurt).The main research areas are Social Pedagogy with the focus on Youth Welfare, Child Protection and Professionality, Family Research, Trauma Research as well as Qualitative Research Methods and Methodology. 